\title{
Different photoprotective responses under drought conditions of two predominant chilean swamp forest species
}

\section{Diferentes respuestas fotoprotectoras bajo condiciones de sequía en dos especies predominantes del bosque pantanoso de Chile}

\author{
Luisa Bascuñán-Godoy ${ }^{1 *}$, Claudia Alcaíno ${ }^{1}$, Danny Eduardo Carvajal ${ }^{1}$, Carolina Sanhueza ${ }^{2}$, Sonia \\ MonteCinos $^{1} \&$ Antonio Maldonado ${ }^{1,3}$ \\ ${ }^{1}$ Laboratorio de Fisiología Vegetal, Centro de Estudios Avanzados en Zonas Áridas, Casilla 599, La Serena, Chile. \\ ${ }^{2}$ Departamento de Botánica, Facultad de Ciencias Naturales y Oceanográficas, Universidad de Concepción, Casilla 160-C, \\ Correo 3, Concepción, Chile. \\ ${ }^{3}$ Departamento de Biología Marina, Universidad Católica del Norte, Larrondo 1281, Coquimbo, Chile. \\ *luisa.bascunan@ceaza.cl
}

\begin{abstract}
Myrceugenia exsucca (DC.) O.Berg (Myrtaceae) and Luma chequen (Molina) A. Gray (Myrtaceae) are two predominants species from swamp forests of Chile. These species present differential microhabitat distribution across soil moisture and north-south precipitation gradients, with only L. chequen being commonly found in lower moisture sites. It is hypothesized that $L$. chequen has greater plasticity than $M$. exsucca in the attributes involved in photoprotection under drought conditions. To test this hypothesis, both species were exposed to short term drought treatment. A group of individuals was maintained irrigated (with $\Psi_{\mathrm{w}}$ of -0.58 and $-0.73 \mathrm{MPa}$ for $M$. exsucca and $L$. chequen, respectively), while another group was exposed to drought treatment with $\Psi_{\mathrm{w}}$ around-1.4 $\mathrm{MPa}\left(\Psi_{\mathrm{w}} \mathrm{D}\right)$. High relationship was founded between relative water content (RWC) and water potential $\left(\Psi_{\mathrm{w}}\right)$ for $M$. exsucca $\left(\mathrm{r}^{2}=0.74\right)$ more than for $L$. chequen $\left(\mathrm{r}^{2}=0.46\right)$, indicating that $M$. exsucca experienced larger dehydration during the drought treatment. As functional attributes of photosynthetic apparatus, amount of total chlorophyll and chlorophyll $a$ fluorescence parameter levels were studied in both species. The results show that $L$. chequen reduced total content of chlorophylls and maximum efficiency of PSII (Fv / Fm) related to decrease of energy capture increasing significantly the thermal dissipation (qN). On the other hand, $M$. exsucca does not change these parameters, but significantly reduced the level of photochemical processes (qL), indicating an energy imbalance. The results indicate $M$. exsucca has less plasticity than $L$. chequen under drought conditions. It is believed that these differences may be crucial in the establishment period and may be influencing the limited distribution of $M$. exsucca in sites with lower water availability.
\end{abstract}

KEYwords: Thermal dissipation, water potential, native plants, Myrtaceae family, wetland plants.

\section{RESUMEN}

Myrceugenia exsucca (DC.) O. Berg (Myrtaceae) y Luma chequen (Molina) A. Gray (Myrtaceae) son dos especies predominantes de los bosques pantanosos en Chile. Estas especies presentan diferente distribución a través de un gradiente de humedad y de precipitaciones, siendo $L$. chequen más común que $M$. exsucca en lugares con menor humedad. En este trabajo se plantea la hipótesis que $L$. chequen presenta una mayor plasticidad que $M$. exsucca de los atributos involucrados en fotoprotección bajo condiciones de sequía. Para comprobar esta hipótesis, individuos de ambas especies fueron expuestos a un tratamiento de sequía. Un grupo de individuos fue mantenido con riego exhibiendo un potencial hídrico $\left(\Psi_{\mathrm{w}}\right)$ óptimo de -0.58 y -0.73 MPa para M. exsucca y L. chequen, respectivamente. Otro grupo fue sometido a sequía, donde el $\Psi_{\mathrm{w}}$ disminuyó a -1.4 MPa $\left(\Psi_{\mathrm{w}} \mathrm{D}\right)$ para ambas especies. Se encontró una mayor correlación entre el contenido relativo de agua $(\mathrm{RWC})$ y $\Psi_{\mathrm{w}}$ para $M$. exsucca $\left(\mathrm{r}^{2}=0.74\right)$ que para $L$. chequen $\left(\mathrm{r}^{2}=0.46\right)$, indicando que $M$. exsucca experimentó una mayor deshidratación que $L$. chequen durante el tratamiento. Como atributos de funcionalidad del aparato fotosintético el nivel de clorofilas y la fluorescencia de la clorofila $a$ fueron estudiados en plantas de ambas especies. Los resultados muestran que L. chequen redujo el contenido total de clorofilas y la eficiencia máxima del PSII (Fv/Fm) relacionado con una disminución de la captura energética e incrementó significativamente la disipación térmica (qN). Por otro lado, $M$. exsucca no mostró cambios en estos parámetros, pero redujo significativamente el nivel de los procesos fotoquímicos (qL), indicando un desbalance energético. Los resultados indican que $M$. exsucca posee una menor plasticidad que $L$. chequen 
bajo condiciones de sequía. Se cree que estas diferencias pueden ser cruciales en el periodo de establecimiento y pueden estar influenciando la limitada distribución de $M$. exsucca en sitios con menor disponibilidad hídrica.

Palabras clave: Disipación térmica, potencial hídrico, plantas nativas, familia Myrtaceae, plantas higrófilas.

\section{INTRODUCTION}

Riparian vegetation dominated by trees is common among Mediterranean and desert ecosystems (Busch \& Smith 1995, Villagrán \& Hinojosa 1997) and correspond to discontinuous and azonal vegetal formation restricted to hydrophilic habitats (Fuenzalida \& Pisano 1965, Maldonado \& Villagrán 2001, Ramírez et al. 1995). It has been reported that riparian vegetation has been related with watercourse protection and biological diversity conservation (Ramírez et al. 1995). In fact, these plants are the refuge for many species of insects and birds (Solervicens \& Elgueta 1994). However, this vegetation is usually under severe threat from human activity such as wood extraction, grazing, water provision and expansion of crop land (Correa-Araneda et al. 2011).

In the Chilean Mediterranean zone, riparian vegetation is characterized by swamp forests dominated by trees and scrub species belonging to the Myrtaceae family, distributed along the coast of north-central Chile from Coquimbo to Los Lagos Region (31-41 ${ }^{\circ} \mathrm{S}$ ) (Villagrán \& Hinojosa 1997). Myrcengenia exsucca (DC.) O. Berg (Myrtaceae) and Luma chequen (Molina) A. Gray (Myrtaceae) are two species considered important within the swamp forest (San Martín et al. 1988). These plants grow together in permanently or semi-permanently flooded soils, however, their microhabitats often differ, with only $L$. chequen being commonly found in lower moisture sites (Landrum 1988). Furthermore, across a north-south gradient of precipitations, $M$. exsucca exhibits a southern distribution between $32^{\circ} \mathrm{S}$ (Coquimbo, Coquimbo Region) and $44^{\circ} \mathrm{S}$ (Llanquihue, Los Lagos Region), while $L$. chequen is extended from $30.5^{\circ} \mathrm{S}$ (Coquimbo, Coquimbo Region) and $42^{\circ} \mathrm{S}$ (Chiloé, Los Lagos Region) (Landrum 1988). The presence of $M$. exsucca in the semiarid regions of its distribution is very limited, and it is considered such a vulnerable species (Arancio et al. 2001). Deforestation and drainage to allow the land to be used for various productive activities (Hauenstein et al. 2005, Peña-Cortés et al. 2011), however, as a consequence these plants have to cope with increments of aridity that could affect central Chile (IPCC, 2007).

Water availability is the primary resource for structuring plant communities in arid and semi-arid regions (Knapp et al. 2002, Bai et al. 2004, Chaves et al. 2009). Water deficit induces stomatal closure to minimize the water losses at expense of reducing $\mathrm{CO}_{2}$ assimilation (Chaves et al. 2002,
Flexas \& Medrano 2002, Herrera et al. 2008). Under these conditions, light incident on the leaf surface exceeds largely the amount that can be used for photosynthesis (DemmigAdams et al. 1996). This excess of absorbed light energy can induce photoinhibition which is a consequence of either reversible down-regulation of PSII through dissipation of excess absorbed energy or irreversible inactivation of PSII and damage to D1 reaction center protein (Demmig-Adams et al. 1996, Niyogi et al. 1998, Aro et al. 1993). However, the plants have developed different mechanisms to prevent photodamage and safely dissipate the excess of absorbed energy to avoid damage to photosynthetic machinery.

Photoprotection may be achieved by decreasing the probability of light absorption through the development of smaller light harvest complex which is reflected in a decrease of chlorophyll amount (Balaguer et al. 2001). If an excess of energy have been absorbed, photoprotection may be accomplished by dissipation through the photochemical use of energy excess (photochemical quenching, qL) or by the non-photochemical quenching of chlorophyll $a$ on the antena (qN). Full qN activation requires quenching of the excess absorbed light in the antenna, via induction of the xanthophyll cycle (Demmig-Adams et al. 1996, Niyogi et al. 1998). There is a substantial evidence that thermal dissipation is responsible for dissipate the majority of excess energy in drought tolerant plants (Savage et al. 2009, García-Plazaola \& Becerril 2000, Galmés et al. 2007). However, it has been suggested that increase of thermal dissipation is not a strategy used by wetland specialist plants under drought (Savage et al. 2009).

There is a large amount of research to concern photoprotective mechanisms under drought conditions, although, most of these studies have been performed in arid ecosystems; such as Mediterranean (Peguero-Pina et al. 2009, Galmés et al. 2007). Considering that drought is the most important environmental constrain that swamp forest plants have for the establishment of seedlings (Savage et al. 2009), physiological studies of drought carried out on azonal vegetation are of great importance.

Considering the limited presence of $M$. exsucca in drier sites, we hypothesized that this species exhibits decreased plasticity of functional attributes related with photoprotection, contrary to $L$. chequen. The knowledge about the energy dissipation performance under drought conditions could be crucial to improve the understanding of the differential distribution of $M$. exsucca and L. chequen in a soil moisture gradient. 


\section{MATERIALS AND METHODS}

Plant MATERial AND TREATMENTS

Seedlings of $M$. exsucca and $L$. chequen with heights of 30 $\mathrm{cm}$ were obtained from a botanical garden (Talca University, Maule Region, Chile). Saplings were maintained outdoors at the University of La Serena (Coquimbo Region, Chile) in plastic pots (of $3 \mathrm{~L}$ ) using a 1:1 mixture of soil:organic substrate, and watered three times a week during one month. Before to starting the experiment, plants were maintained for four weeks in a controlled growth chamber at $21^{\circ} \mathrm{C}$ with a photon flux density of about $300 \mu \mathrm{mol}$ of photons $\mathrm{m}^{-2}$ $\mathrm{s}^{-1}$ provided by sodium lamps (Son/T Agro $400 \mathrm{~W}$, Philips, Eindhoven, The Netherlands) with $12 \mathrm{~h}$ photoperiod. Plants were irrigated and supplied weekly with $50 \%$ Hoagland's solution.

To assess the physiological performance of both species, plants were separated in two groups. The first with similar irrigation timetable (control group) and the second group was subjected to drought by suspended irrigation (drought treatment).

\section{Plant Water status}

Midday stem water potential $\left(\Psi_{\mathrm{w}}\right)$ and relative leaf water content (RWC) was monitored at 0,4 and 10 days from start the drought treatment. $\Psi_{\mathrm{w}}$ was measured in excised secondary branches using a pressure chamber type Scholander (Soil Moisture Equipment Corp., USA). RWC was calculated in leaves of six different individuals for each species and treatment as described by Turner (1981): RWC $=($ fresh weight - dry weight)/(turgid weight - dry weight $) \times 100$. The turgid leaf weight was determined after keeping the leaf in distilled for $24 \mathrm{~h}$. Leaf dry weight was obtained after keeping the turgid leaf for $48 \mathrm{~h}$ in an oven at $70^{\circ} \mathrm{C}$.

The water stress levels were tested in control plants with optimal $\Psi_{\mathrm{w}}\left(\Psi_{\mathrm{w}} \mathrm{C}\right)$ and plants submitted to drought by 10 days reaching around -1.4 MPa of $\Psi_{\mathrm{w}}\left(\Psi_{\mathrm{w}} \mathrm{D}\right)$.

\section{Chlorophyll $A$ FLUORESCENCE MEASUREMENTS}

Chlorophyll fluorescence signals were analyzed in leaves of secondary branches from six different individuals using a portable fluorometer (FMS 2, Hansatech Instruments Ltd., Norfolk, UK). All measurements were done with the same hardware configuration using an actinic light of $300 \mu \mathrm{mol}$ $\mathrm{m}^{-2} \mathrm{~s}^{-1}$. Definitions of fluorescence parameters: maximum PSII efficiency ( $\mathrm{Fv} / \mathrm{Fm})$, electron transport rate (ETR) and non-photochemical quenching (qN) were used as described by Maxwell \& Johnson (2000) except for photochemical quenching (qL), which was calculated as described in Kramer et al. (2004).

\section{ChLOROPHYLLS AMOUNT ANALYSIS}

The chlorophylls amount analysis were performed in leaves of secondary branches of six individuals of each species exposed to two different water conditions. Chlorophylls were extracted in $90 \%$ of ethanol overnight and centrifuged at $12,000 \mathrm{~g}$ for $10 \mathrm{~min}$. Total chlorophylls content were determined spectrophotometrically at 663 and $645 \mathrm{~nm}$ according to Arnon (1949) as follow: Total Chl $\left(\mathrm{g} \mathrm{l}^{-1}\right)=$ $0.0202 \mathrm{~A} 663+0.00802 \mathrm{~A} 645$.

Statistical ANALYsis

Statistical analyses of data were performed with the STATISTICA 6.0 software. One-way ANOVA were performed for the studied parameters with the treatment as factor. Differences between means were evaluated by Tuckey test $(P<0.05)$.

\section{RESULTS}

EFFECT OF DROUGHT ON THE RELATIONSHIP BETWEEN RWC AND WATER POTENTIAL $\left(\boldsymbol{\Psi}_{\mathrm{W}}\right)$

Mean water potential under control conditions $\left(\Psi_{\mathrm{w}} \mathrm{C}\right)$ were $-0.58 \pm 0.06$ and $-0.73 \pm 0.04 \mathrm{MPa}$ for $M$. exsucca and $L$. chequen, respectively (Fig. 1). $\Psi_{\mathrm{w}}$ decreased significantly during the drought treatment in both species to $-1.4 \pm 0.11$ and $-1.4 \pm 0.09 \mathrm{MPa}$, for $M$. exsucca and $L$. chequen respectively $(\mathrm{P}<0.01)$. Drought stressed plants of $M$. exsucca reduced $37 \%$ its RWC, while $L$. chequen experienced a reduction only in $12 \%$, respect to control plants. Higher relationship between RWC and $\Psi_{\mathrm{w}}$ was observed for $M$. exsucca $\left(\mathrm{r}^{2}=\right.$ $0.72, \mathrm{P}<0.01)$, than for L. chequen $\left(\mathrm{r}^{2}=0.42, \mathrm{P}<0.01\right)$ during the drought treatment (Fig. 1). Differences in RWC between species were observed from $-1.0 \mathrm{MPa}$, where $L$. chequen maintain its leaf RWC close to $65 \%$ despite the decrease in $\Psi_{\mathrm{w} .}$

Changes ON CHLOROPHYLl FLUORESCENCE PARAMETERS IN RESPONSE TO $\boldsymbol{\Psi}_{\mathrm{W}}$ DECLINE

Under $\Psi_{\mathrm{w}} \mathrm{C} \mathrm{Fv} / \mathrm{Fm}$ values were optimal in both species $(\sim 0.8)$. The decrease of water potential to $-1.4 \mathrm{MPa}\left(\Psi_{\mathrm{w}} \mathrm{D}\right)$ induce significant decrease of $\mathrm{Fv} / \mathrm{Fm}$ in $L$. chequen $(\stackrel{\mathrm{W}}{P}<$ 0.05), but not in M. exsucca (Fig. 2A).

ETR was maintained in both species along the treatment (Fig. 2B), however the proportion of photochemical processes (qL) decreased significantly (31\%) in $M$. exsucca and were maintained in L. chequen (Fig. 2C).

Both species exhibited high values of qN under $\Psi_{\mathrm{w}} \mathrm{C}$ (Fig. 2D), however, decrease to $-1.4 \mathrm{MPa}\left(\Psi_{\mathrm{w}} \mathrm{D}\right)$ during the drought treatment, induced a significant increment of $\mathrm{qN}$ in L. chequen $(P<0.05)$.

Chlorophyll Changes PeRCENT In RESPONSE to DeCline of $\boldsymbol{\Psi}_{\mathrm{w}}$ Total chlorophylls were maintained in $M$. exsucca during the treatment, however, $L$. chequen experienced a significant $20 \%$ decrease under $\Psi_{\mathrm{w}} \mathrm{D}(\mathrm{P}<0.01)$ (Fig. 3). 


\section{DISCUSSION}

Our results shown that $L$. chequen is more plastic than M. exsucca in many traits during the switch from control conditions to drought, in special the related with the control of water consume and protection of photosynthetic apparatus.

M. exsucca showed faster dehydration than $L$. chequen when decrease $\Psi_{\mathrm{w}}$. This response may indicate a poor osmotic adjustment capacity affecting its water status greater under drought compared with $L$. chequen (Fig. 1). Plant drought response strategies are generally broken into two categories: drought avoidance and drought tolerance. The high water consumption showed by $M$. exsucca is a typical characteristic from plants with strategies of drought avoidance (Touchette et al. 2007). Although, M. exsucca rarely experience severe drought in its natural habitats, this result is important considering its classification such a vulnerable species and with the increment of aridity in many regions of its habitats distribution.

Decrease in leaf chlorophyll content and $\mathrm{Fv} / \mathrm{Fm}$ reduction is a common response of Mediterranean plants to summer (Balaguer et al. 2002). Loss of upon 50\% of leaf chlorophyll does not lead to leaf senescence in drought tolerant plants species such as Quercus coccifera, Quercus ilex, Salix bebbiana (Peguero-Pina et al. 2009, Balaguer et al. 2002), but rather than constitutes a reversible process that allows decrease the light harvesting and reduce risks of over-excitation and photodamage (Balaguer et al. 2002). In this work it is suggested that the reduction of the antenna size evidenced by a decrease of chlorophylls amount in L. chequen (Fig. 3), allows maintain PSII functionality and electron transport. In addition, the increase of qN under drought in $L$. chequen (Fig. 2D) suggests that Fv/Fm decrease (Fig. 2A) is not attributable to photodamage of PSII, however, this may be considered as a protective strategy contributing to dissipate excess of energy (Krause 1988, Osmond 1994). It has been shown that large induction of thermal dissipation and xanthophyll cycle deepoxidation under drought, has greater importance in many Mediterranean species with habitat generalist (Chaves et al. 2002, Galmes et al. 2007), but not in wetland specialist species (Savage et al. 2009). Our work is one of the first works that suggest the thermal dissipation may be an efficient strategy under drought for a swamp forest plant: L. chequen, which shows a high plasticity of its photosynthetic apparatus performance under water stress.

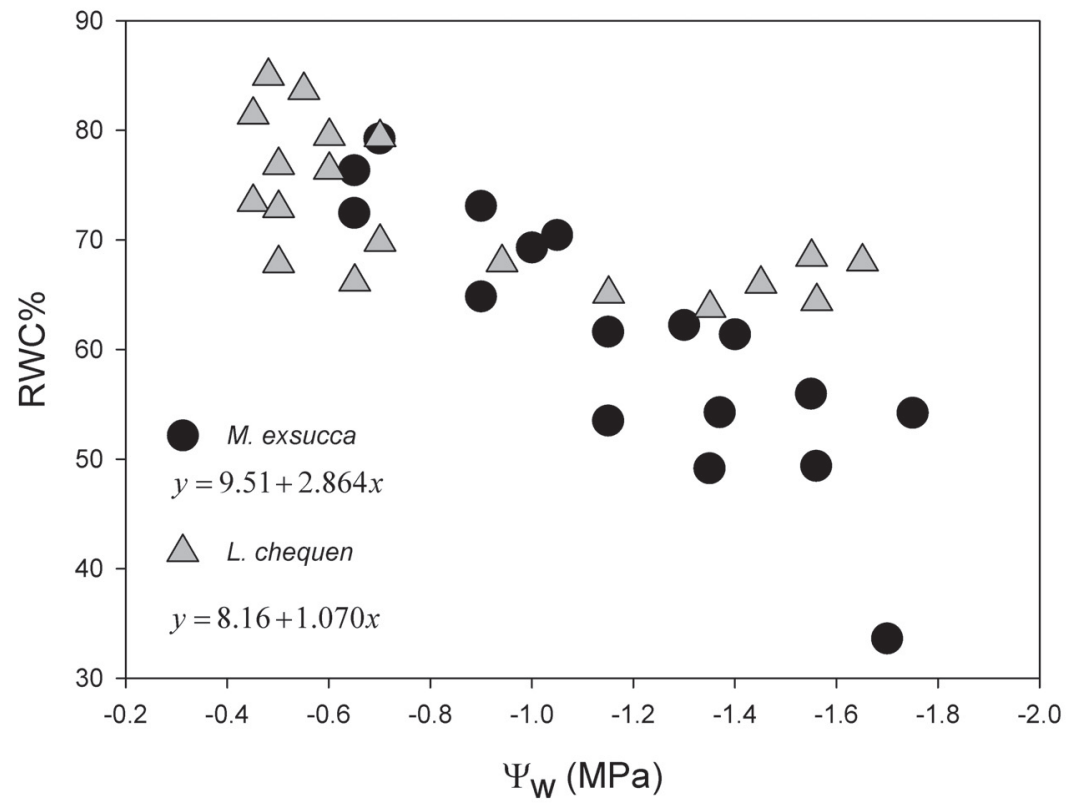

Figure 1. Relationship between leaf RWC and $\Psi_{\mathrm{w}}$ for $M$. exsucca (black circles) and L. chequen (gray triangles) exposed to progressive drought. Dates correspond to 0, 4 and 10 days of the drought treatments. Equations in the graphics correspond to simple linear regression of M. exsucca $\left(\mathrm{r}^{2}=0.74\right)$ and L. chequen $\left(\mathrm{r}^{2}=0.46\right)$.

Figura 1. Correlación entre CRA y $\Psi_{\mathrm{w}}$ para $M$. exsucca (círculos negros) y $L$. chequen (triángulos de color gris) bajo condiciones de sequía progresiva. Los datos corresponden a los días 0,4 y 10 del tratamiento de sequía. Ecuaciones en los gráficos corresponden a regresión lineal simple de $M$. exsucca $\left(\mathrm{r}^{2}=0,74\right)$ y L. chequen $\left(\mathrm{r}^{2}=0,46\right)$. 


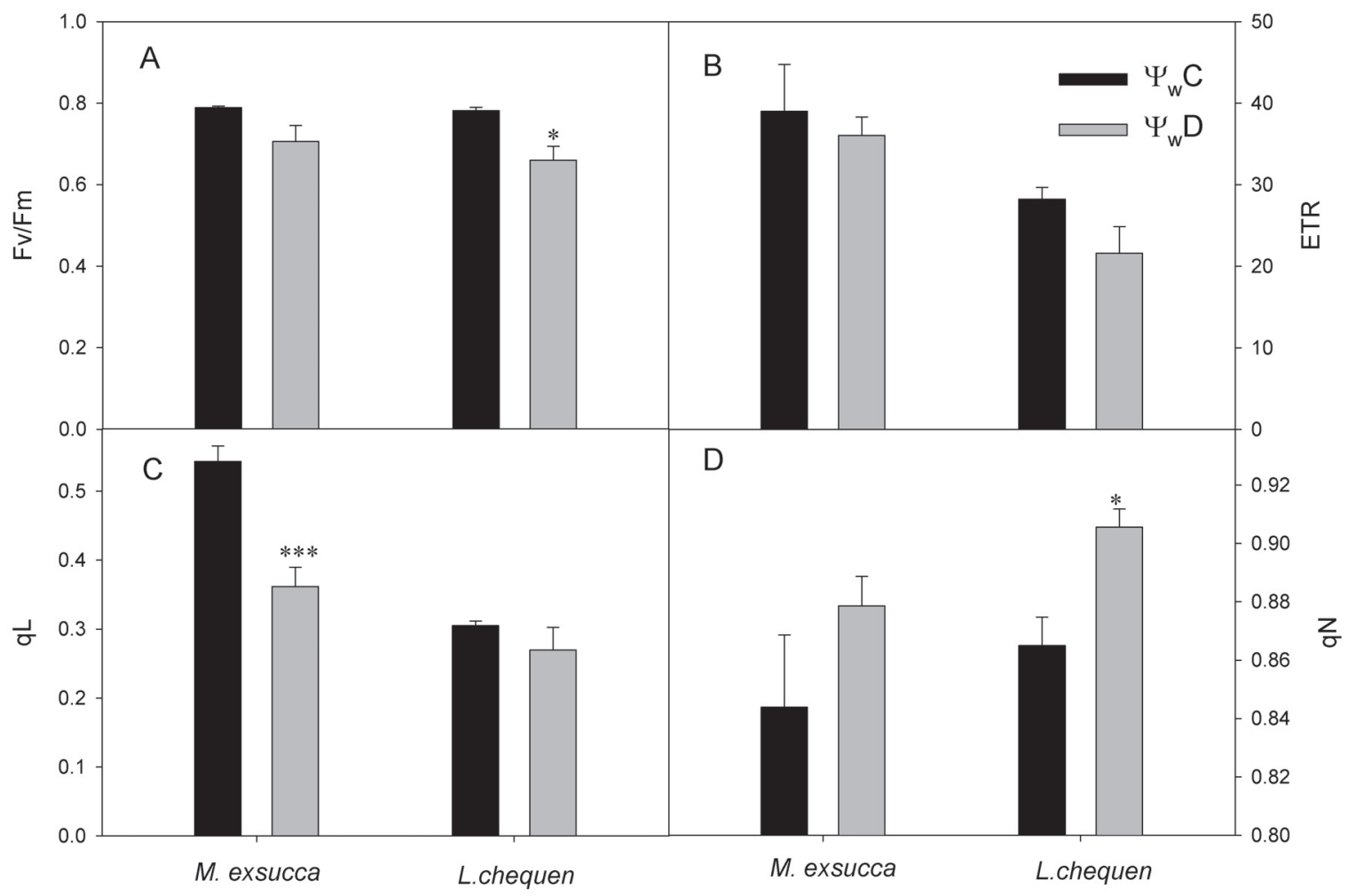

Figure 2. (A) Maximal photochemical efficiency (Fv/Fm), (B) electron transport rate (ETR), (C) the proportion of photochemical process $(\mathrm{qL})$ and $(\mathrm{D})$ non-photochemical quenching changes $(\mathrm{qN})$ in response to decline of water potential $\left(\Psi_{\mathrm{w}}\right)$ from optimal $\left(\Psi_{\mathrm{w}} \mathrm{C}\right)$ to stressed conditions $\left(\Psi_{\mathrm{w}} \mathrm{D}\right) . \Psi_{\mathrm{w}} \mathrm{C}=-0.7 \mathrm{MPa}$ and $\Psi_{\mathrm{w}} \mathrm{D}=-1.4 \mathrm{MPa}$ for $M$. exsucca; $\Psi_{\mathrm{w}} \mathrm{C}=-0.5 \mathrm{MPa}$ and $\Psi_{\mathrm{w}} \mathrm{D}=-1.4 \mathrm{MPa}$ for $L$. chequen. Measurements of chlorophyll $a$ fluorescence parameters were done at room temperature using $300 \mu$ moles of photons $\mathrm{m}^{-2} \mathrm{~s}^{-1}$ of actinic light. Values represent mean \pm standard error of six replicates. $*$ and $* * *$ denote statistical differences of chlorophyll $a$ fluorescence parameters analyzed by Tuckey test $(P<0.05$ and $P<0.01$, respectively) among treatments.

FIGURA 2. (A) Eficiencia fotoquímica máxima del PSII (Fv/Fm), (B) tasa de transporte de electrones (ETR), (C) la proporción de procesos fotoquímicos $(\mathrm{qL})$ y $(\mathrm{D})$ no fotoquímicos $(\mathrm{qN})$ en respuesta a la disminución del potencial hídrico desde condiciones control $\left(\Psi_{\mathrm{w}} \mathrm{C}\right)$ a estrés por sequía $\left(\Psi_{\mathrm{w}} \mathrm{D}\right) . \Psi_{\mathrm{w}} \mathrm{C}=-0.7 \mathrm{MPa}$ y $\Psi_{\mathrm{w}} \mathrm{D}=-1.4 \mathrm{MPa}$ para $M$. exsucca; $\Psi_{\mathrm{w}} \mathrm{C}=-0.5 \mathrm{MPa}$ y $\Psi_{\mathrm{w}} \mathrm{D}=-1.4 \mathrm{MPa}$ para $L$. chequen. Las mediciones de los parámetros de la fluorescencia de la clorofila $a$ se realizaron a temperatura ambiente con $300 \mu$ moles de fotones $\mathrm{m}^{-2} \mathrm{~s}^{-1}$ de luz actínica. Los valores representan la media \pm error estándar de seis repeticiones. * y *** denotan diferencias estadísticas de los parámetros analizados por el test de Tuckey ( $\mathrm{P}<0,05$ y $\mathrm{P}<0,01$, respectivamente) entre tratamientos.

Contrasting to L. chequen, M. exsucca showed a lower plasticity in the traits studied under drought. M. exsucca maintained chlorophyll levels (Fig. 3) and maximum photosynthetic efficiency during drought, which could indicate a sustained light capture and exhibited not significant perturbation on PSII capacity, despite the important reduction of RWC. A similar response was observed in the tropical shrub Lycium nodosum (Solanaceae) and the ericaceous Erica multiflora and Calluna vulgaris, where Fv/Fm was unchanged across a comparable range of water deficit stress (Tezara et al. 2003, Llorenz et al. 2004). However, M. exsucca reduced considerably qL (Fig. 2C), without significant changes in qN (Fig. 2D), indicating an energetic imbalance. If the excess energy is not dissipated by $\mathrm{qN}$ as heat, either at photochemical level, this could induce ROS formation by excessive reduction of electron transport chain (Krause 1988, Osmond 1994). Although no signal of photodamage to
PSII (measured as decrease of Fv/Fm, ETR or chlorophylls content) were observed in $M$. exsucca during the 10 days under drought treatment, the individuals experienced leave abscission after 30 days of drought. There is evidence that photoinhibition play a role in senescence (Rivero et al. 2007). However, if these plants experienced photoinhibition was undetected, because unfortunately we did not Fv/Fm measurements immediately before to senescence of the individual leaves. We think that poor adjustments of the traits related with photoprotection of photosynthesis could explain the restricted distribution of $M$. exsucca under lower soils moisture. It has been postulated that leaf abscission results crucial as survival mechanisms to avoid water loss (Touchette et al. 2007). However, this strategy results in a decline of carbon metabolism associated with a high energy cost affecting the establishment of seedlings (Touchette et al. 2007, Rivero et al. 2007). 


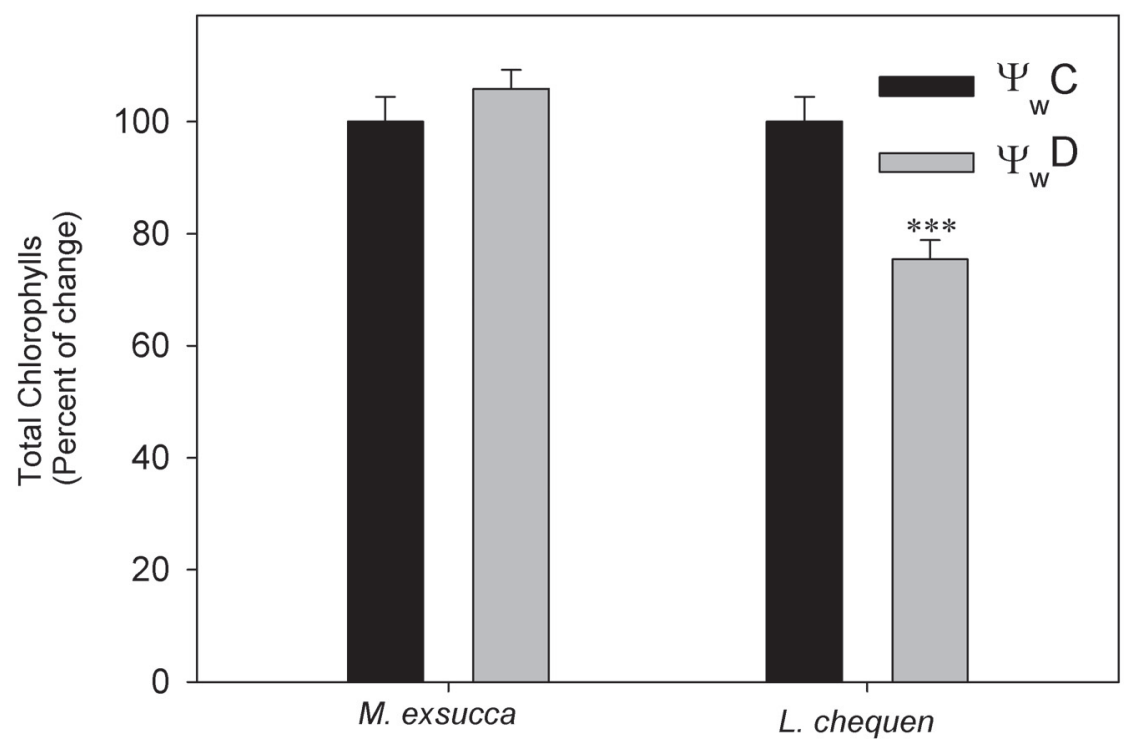

Figure 3. Percent change of chlorophylls amount in response to decline of water potential $\left(\Psi_{\mathrm{w}}\right)$ from optimal $\left(\Psi_{\mathrm{w}} \mathrm{C}\right)$ to stressed conditions $\left(\Psi_{\mathrm{w}} \mathrm{D}\right) . \Psi_{\mathrm{w}} \mathrm{C}=-0.7 \mathrm{MPa}$ and $\Psi_{\mathrm{w}} \mathrm{D}=-1.4 \mathrm{MPa}$ for M. exsucca; $\Psi_{\mathrm{w}} \mathrm{C}=-0.5 \mathrm{MPa}$ and $\Psi_{\mathrm{w}} \mathrm{D}=-1.4 \mathrm{MPa}$ for $L$. chequen. Values represent mean \pm standard error of six replicates. * and *** denote statistical differences of chlorophyll $a$ fluorescence parameters analyzed by Tuckey test $(P<0.05$ and $P<0.01$, respectively) among treatments.

Figura 3. Porcentaje de cambio del contenido de clorofilas en respuesta a la disminución del potencial hídrico desde condiciones control $\left(\Psi_{\mathrm{w}} \mathrm{C}\right)$ a estrés por sequía $\left(\Psi_{\mathrm{w}} \mathrm{D}\right) . \Psi_{\mathrm{w}} \mathrm{C}=-0.7 \mathrm{MPa}$ y $\Psi_{\mathrm{w}} \mathrm{D}=-1.4 \mathrm{MPa}$ para $M$. exsucca; $\Psi_{\mathrm{w}} \mathrm{C}=-0.5 \mathrm{MPa}$ y $\Psi_{\mathrm{w}} \mathrm{D}=-1.4 \mathrm{MPa}$ para $L$. chequen. Los valores representan la media \pm error estándar de seis repeticiones. * $\mathrm{y} * * *$ denotan diferencias estadísticas de los parámetros analizados por el test de Tuckey ( $\mathrm{P}<0,05$ y $\mathrm{P}<0,01$, respectivamente) entre tratamientos.

Possible limitation of this work was the low light intensity $\left(300 \mu \mathrm{mol}\right.$ of photons $\left.\mathrm{m}^{-2} \mathrm{~s}^{-1}\right)$, because the impact of drought on photochemical performance is presumably greater under natural light conditions. This is mainly due to tissue desiccation combined with high temperature may produce photo-oxidative stress with a direct impact on seedling survival and growth (Balaguer et al. 2001, Balaguer et al. 2002). Although, is expected that plants grown under natural conditions develop several morphological attributes to regulate the energy absorbed such as a thicker parenchyma and mesophyll cells with smaller chloroplasts (Anderson 1986, Melis 1991).

Finally, our results demonstrate that photoprotective strategies seem to vary with the habitat distribution of the species. $M$. exsucca which inhabits in more wetland soils, loses water easier than L. chequen and show lower plasticity of its photosynthetic apparatus related traits. On the other hand, L. chequen which can grow in drier sites displays a high plasticity of biochemical mechanisms allowing adjustment of photochemical processes under drought conditions. The strategies reported here could be especially important in the establishment of seedlings under low moisture soil and probably may determine the distribution of these species. These results are important considering the aridity increase in the central zone and the conservative role that these plants have in the swamp forest.

\section{ACKNOWLEDGMENTS}

L. Bascuñán-Godoy and A. Maldonado thanks FONDECYT 11070016 and CEAZA for supporting this work. D. Carvajal is grateful to the Instituto de Ecologia y Biodiversidad for scholarship.

\section{REFERENCES}

Arancio, G., M. Muñoz \& F.A. Squeo. 2001. Descripción de algunas especies con problemas de conservación en la IV Región de Coquimbo, Chile. En: F.A. Saqueo, G. Arancio \& J.R. Gutiérrez (eds.), Libro rojo de la flora nativa y de los sitios prioritarios para su conservación: Región de Coquimbo, Vol. 6, pp. 63-103. Ediciones Universidad de La Serena, La Serena, Chile.

Arnon, D. 1949. Copper enzymes in isolated chloroplasts; polyphenol oxidases in Beta vulgaris. Plant Physiology 24:1-15.

Aro, E.M., I. Virgin \& B. Andersson. 1993. Photoinhibition of photosystem II: inactivation, protein damage and turnover. Biochimica et Biophysica Acta 1143: 113-134.

Anderson, K.M. 1986. Photoregulation of the composition, function and structure of thylakoid membranes. Annual Review of Plant Physiology 37:93-136.

BaI, Y., X. HAn, J. Wu, Z. Chen \& L. Li. 2004. Ecosystem stability and compensatory effects in the Inner Mongolia grassland. 
Nature 431:181-184.

Balaguer L., F.I. Pugnaire, E. Martínez-Ferri, C. Armas \& F. VAlladares. 2002. Ecophysiological significance of chlorophyll loss and reduced photochemical efficiency under extreme aridity in Stipa tenacissima L. Plant and Soil 240: 343-352.

Balaguer, L., E. Martínez-Ferri, F. Valladares, M.E. PérezCorona, F.J. Baquedano, F.J. Castillo \& E. Manrique. 2001. Population Divergence in the Plasticity of the Response of Quercus coccifera to the Light Environment. Functional Ecology Balaguer 15(1): 124-135.

Busch, D.E. \& S.D. SмITH. 1995. Mechanisms associated with decline of woody species in riparian ecosystems of the Southwestern U.S. Ecological Monographs 65: 347-370.

Chaves, M., J.S. Pereira, J. Maroco, M.L. Rodrigues, C.P.P. Ricardo, M.L. CARVAlHo Osório, I. Carvalho, T. Faria \& C. PInHeIro. 2002. How plants cope with water stress in the field. Photosynthesis and growth. Annals of Botany 89: 907-916.

Chaves, M.M., J. Flexas \& C. Pinheiro. 2009. Photosynthesis under drought and salt stress: regulation mechanisms from whole plant to cell. Annals of Botany 103: 551-560.

Correa-Araneda F., J. Urrutia \& R. Figueroa. 2011. Estado del conocimiento y principales amenazas de los humedales boscosos de agua dulce de Chile. Revista Chilena de Hhistoria Natural 84: 325-340.

Demmig-Adams, B., A.M. Gilmore \& W.W.III. Adams. 1996. In vivo functions of carotenoids in higher plants. FASEB Journal 10: 403-412.

Flexas, J. \& H. Medrano. 2002. Drought-inhibition of photosynthesis in $\mathrm{C}_{3}$ plants: stomatal and non-stomatal limitations revisited. Annals of Botany 89: 183-189.

Fuenzalida, H. \& E. Pisano. 1965. Biogeografía. En: Geografía Económica de Chile, Vol 1, pp. 228-267. Corporación de Fomento de la Producción, Santiago, Chile.

Galmés, J., A. Abadía, J. Cifre, H. Medrano \& J. Flexas. 2007. Photoprotection processes under water stress and recovery in Mediterranean plants with different growth forms and leaf habits. Physiologia Plantarum 130, 495-510.

García-Plazaola, J.I. \& J.M. Becerril. 2000. Effects of drought on photoprotective mechanisms in European beech (Fagus sylvatica L.) seedlings from different provenances. Trees Structure and Function 14, 485-490.

Hauenstein, E., M. González, F. Peña-Cortés \& A. MuñozPedreros. 2005. Diversidad vegetal en humedales costeros de la Región de La Araucanía. En: C. Smith-Ramírez, J.J. Armesto, C. Valdovinos (eds.), Historia, biodiversidad y ecología de los bosques costeros de Chile, Vol. 1, pp. 197209. Editorial Universitaria, Santiago, Chile.

Herrera, A., W. Tezara, O. Marin \& E. Rengifo. 2008. Stomatal and non-stomatal limitations of photosynthesis in trees of a tropical seasonally flooded forest. Physiologia Plantarum 134: 41-48.

IPCC, 2007. Cambio climático 2007: Informe de síntesis. Contribución de los Grupos de trabajo I, II y III al Cuarto Informe de evaluación del Grupo Intergubernamental de Expertos sobre el Cambio Climático [Equipo de redacción principal: R.K. Pachauri \& A. Reisinger (directores de la publicación)]. IPCC, Ginebra, Suiza, 104 pp.

Knapp, A.K., P.A. Fay, J.M. Blair, S.L. Collins, M.D. Smith, J.D.
Carlisle, C.W. Harper, B.T. Danner, M.S. Lett \& J.K. MCCARRon. 2002. Rainfall variability, carbon cycling, and plant species diversity in a mesic grassland. Science 298: 2202-2205.

Kramer, D.M, G. Johnson, O. KirRats \& G.E. Edwards. 2004. New fluorescence parameters for the determination of $\mathrm{Q}(\mathrm{A})$ redox state and excitation energy fluxes. Photosynthesys Research 79: 209-218.

Krause, G.H. 1988. Photoinhibition of photosynthesis. An evaluation of damaging and protective mechanisms. Physiologia Plantarum 74: 566-74.

Landrum, L.R. 1988. The Myrtle Family (Myrtaceae) in Chile. Proceedings of the California Academy of Sciences 45: 277-317.

Llorens, L., J. Peñuelas, C. Beier, B. Emmett, M. Estiart \& A. Tietema. 2004. Effects of an experimental increase of temperature and drought on the photosynthetic performance of two ericaceous shrub species along a North-South European gradient. Ecosystems 7: 613-624.

Maldonado, A. \& C. Villagrán. 2001. Historia del bosque pantanoso de Ñague, costa de Los Vilos (IV Región, Chile) y sus relaciones con los cambios paleoambientales de los últimos 5.300 años A.P. En: F.A. Squeo, G. Arancio \& J.R. Gutiérrez (eds.). Libro rojo de la flora nativa y de los sitios prioritarios para su conservación: Región de Coquimbo, Vol. 17, pp. 261-272. Ediciones Universidad de La Serena, La Serena, Chile.

Maxwell, K. \& G.N. Johnson. 2000. Chlorophyll fluorescence- a practical guide. Journal of Experimental Botany 51: 659668.

Melis, A. 1991. Dynamics of photosynthetic membrane composition and function. Biochimica et Biophysica Acta 1058: 87-106.

Niyogi, K.K., A.R. Grossman \& O. Buorkman. 1998. Arabidopsis mutants define a central role for the xanthophyll cycle in the regulation of photosynthetic energy conversion. Plant Cell 10: 1121-1134.

Osmond, C.B. 1994. What is photoinhibition? Some insights from comparisons of shade and sun plants. In: N.R. Baker and J.R. Bowyer (eds.), Photoinhibition of Photosynthesis. From Molecular Mechanisms to the Field, Vol 1, pp 1-24. Bios Scientific, Oxford, UK.

Peguero-Pina, J.J., D. Sancho-Knapik, F. Morales, J. Flexas \& E. Gil-Pelegrin. 2009. Differential photosynthetic performance and photoprotection mechanisms of three Mediterranean evergreen oaks under severe drought stress. Functional Plant Biology 36: 453-462.

Peña-Cortés F., J. Pincheira-Ulbrich, C. Bertrán J. Tapia, E. Hauenstein, E. Fernández \& D. Rozas. 2011. A study of the geographic distribution of swamp forest in the coastal zone of the Araucanía Region, Chile. Applied Geography 31: 545-555.

Ramírez, C., C. SAn Martín \& J. SAn Martín. 1995. Estructura florística de los bosques pantanosos de Chile Sur-Central. En: J.J. Armesto, C. Villagrán \& M.T.K. Arroyo (eds.), Ecología del bosque nativo de Chile, Vol. 1, pp. 215-234. Ediciones Universitaria, Santiago, Chile.

Rivero, R.M., M. Kojima, A. Gepstein, H. Sakakibara, R. Mittler, S. Gepstein \& E. Blumwald. 2007. Delayed leaf senescence induces extreme drought tolerance in a 
Photoprotective responses of two Chilean swamp forest species: BASCUÑÁN-Godoy, L. ET AL.

flowering plant. Proceedings of the National Academy of Sciences 104:19631-19636.

San Martín, J., A. Troncoso \& C. Ramírez. 1988. Estudio fitosociológico de los bosques pantanosos nativos de la cordillera de la Costa en Chile central. Bosque 9: 17-33.

Savage, J.A., J. Cavender-Bares \& A. Verhoeven. 2009. Willow species (genus: Salix) with contrasting habitat affinities differ in their photoprotective responses to water stress. Functional Plant Biology 36:300-309.

Solervicens, J. \& M. Elgueta. 1994. Insectos de follaje de bosques pantanosos del Norte Chico, Centro y Sur de Chile. Revista Chilena de Entomología 21: 135-164.
Tezara, W., D. Martínez, E. Rengifo \& A. Herrera. 2003. Photosynthetic responses of the tropical spiny shrub Lycium nodosum (Solanaceae) to drought, soil salinity and saline spray. Annals of Botany 92: 757-765.

Touchette, B.W., L.R. Iannacone, G.E. Turner \& A.R. Frank. 2007. Drought tolerance versus drought avoidance: A comparison of plant-water relations in herbaceous wetland plants subjected to water withdrawal and repletion. Wetlands 27(3): 656-667.

Villagrán, C. \& L.F. Hinojosa. 1997. Historia de los bosques del sur de Sudamérica, II: Análisis fitogeográfico. Revista Chilena de Historia Natural 70: 241-267.

Recibido: 10.09 .12

Aceptado: 03.04.13 